\title{
GENETIC CONTROL OF WHEAT SEEDLING ROOT GROWTH
}

\author{
Carlos Eduardo de Oliveira Camargo*; Antonio Wilson Penteado Ferreira Filho \\ IAC - Centro de Análise e Pesquisa Tecnológica do Agronegócio de Grãos e Fibras, C.P. 28 - 13001-970 - Campinas, \\ SP - Brasil. \\ *Corresponding author <ccamargo@iac.sp.gov.br>
}

\begin{abstract}
Wheat cultivars should have long primary roots to allow good crop establishment, considering the short crop establishment season (April) in the State of São Paulo, Brazil, where the occurrence of water stress is frequent. This paper demonstrates the control and type of inheritance of the primary root growth trait. Crosses were made between genotypes, BH-1146 and KAUZ "S"/IAC-24 $\mathrm{M}_{4}$ with strong and reduced primary root growth, respectively. $\mathrm{F}_{2}$ and $\mathrm{F}_{3}$ generation seeds from these crosses and $\mathrm{F}_{2}$ generation seeds from the backcrosses of both parents were also obtained. Seedlings from these genotypes plus the parentals were evaluated in relation to primary root growth in complete nutrient solutions containing $3.875 \mathrm{mg} \mathrm{L}^{-1}$ phosphorus, at $\mathrm{pH} 4.0$ and a temperature of $25 \pm 1^{\circ} \mathrm{C}$ for 10 days. Control of the primary root growth trait was demonstrated to have quantitative inheritance. The degrees of dominance showed that the genes for strong root growth had a partially recessive behavior. Heterosis and heterobeltiosis values were negative. The estimated broad-sense heritability for root growth indicated that a great part of the observed variation was of genetic origin. The narrow-sense heritability indicated that a great part of the total genetic variability in relation to the trait under consideration is due to a small number of genes. Considering the estimated coefficient of determination, selection for strong root growth would be effective even when made in the early segregant generations after the cross.
\end{abstract}

Key words: Triticum aestivum, root growth, nutrient solution, recessive genes

\section{CONTROLE GENÉTICO DO CRESCIMENTO RADICULAR DE PLÂNTULAS DE TRIGO}

\begin{abstract}
RESUMO: Os cultivares de trigo devem apresentar raízes primárias longas para permitir um bom estabelecimento da cultura, considerando o curto período de estabelecimento da cultura (abril) no Estado de São Paulo, onde é freqüente a ocorrência de estresse hídrico. Este trabalho visa demonstrar o controle e o tipo de herança envolvida na expressão do caracter crescimento da raiz primária. Foram feitos cruzamentos entre os cultivares BH-1146 e KAUZ "S"/IAC-24 M com grande e reduzido crescimento das raízes primárias, respectivamente. Sementes em gerações $\mathrm{F}_{2}$ e $\mathrm{F}_{3}$ desses cruzamentos e em geração $\mathrm{F}_{2}$ dos retrocruzamentos para ambos os genitores foram também obtidas. Avaliaram-se plântulas dessas populações mais os parentais quanto ao crescimento das raízes primárias, em soluções nutritivas completas com 3,875 $\mathrm{mg} \mathrm{L}^{-1}$ de fósforo, $\mathrm{pH}$ de 4,0 e temperatura de $25 \pm 1^{\circ} \mathrm{C}$, durante dez dias. O controle do crescimento das raízes primárias foi demonstrado ter herança quantitativa. Os graus de dominância mostraram que os genes para maior crescimento das raízes tiveram um comportamento parcialmente recessivo. Os valores para heterose e heterobeltiose para a geração $\mathrm{F}_{2}$ foram negativos. Os valores da herdabilidade em sentido amplo para o crescimento das raízes indicaram ser de origem genética grande parte da variação observada nas populações estudadas. A herdabilidade no sentido restrito indicou que grande parte da variabilidade genética total para esta característica deve-se a poucos genes. Com base na estimativa do coeficiente de determinação, sugere-se que a seleção para esta característica seria efetiva mesmo se realizada nas primeiras gerações segregantes.
\end{abstract}

Palavras-chave: Triticum aestivum, crescimento das raízes, soluções nutritivas, genes recessivos

\section{INTRODUCTION}

Wheat in the State of São Paulo, Brazil, is grown in acid soils under dryland conditions, in the period from April to August, in succession to soybean and corn. The occurrence of toxic levels of aluminum, especially in acid soils, has been reported by many researchers as very common in the Brazilian Cerrado region. This makes plants more sensitive to drought by preventing them from obtaining water from deeper soil layers (Foy et al., 1965; Campbell \& Lafever, 1976; Camargo, 1985).

Wheat genotype evaluations for aluminum toxicity tolerance using nutrient solutions has shown that 
cultivar BH-1146 and line 25 (KAUZ"S"/IAC-24 M ) were tolerant (Camargo, 1993; Camargo et al., 2002). The most productive genotypes in acid soils were those that exhibited aluminum toxicity tolerance in nutrient solutions (Camargo \& Oliveira, 1981; Camargo et al., 1984; Baier et al., 1995).

Mutant lines obtained by gamma irradiation of the cultivar Anahuac (sensitive to aluminum toxicity) present high aluminum toxicity tolerance, which is due to a single pair of dominant alleles. These alleles express the same tolerance as cultivars BH-1146 and IAC-24 (Camargo et al., 1997; 2000).

In addition to the selection of lines that exhibit $\mathrm{Al}^{3+}$ tolerance (Camargo, 1993), the selection of lines of plants that have long primary roots in the initial stages of development is of great importance, considering the short crop establishment period (April) when the occurrence of water stress is frequent, to allow good development of the crop (Camargo \& Ferreira Filho, 2000).

The objective of this study was to obtain information on the type of inheritance involved in the expression of stronger root growth in wheat cultivar BH-1146 at the initial stages of development (7 and 15 days).

\section{MATERIAL AND METHODS}

Crosses were made between wheat genotypes BH-1146 (P6) and KAUZ "S"/IAC-24 M 4 (P25), tolerant to aluminum toxicity, which have strong and reduced primary root growth, respectively (Camargo et al., 2002; 2004). Seedlings from the parentals, $F_{2}$ and $F_{3}$ generation seedlings from the cross between the parentals from individual $F_{1}$ and $F_{2}$ generation plants, in addition to $F_{2}$ generation seedlings from backcrosses for both parentals also from individual $F_{1}$ generation plants were submitted to a ten-day growth period in nutrient solutions using the following technique:

Seeds from the populations were washed with a $10 \%$ sodium hypochlorite solution and placed to germinate in a refrigerator at a temperature of $12^{\circ} \mathrm{C}$ for 72 hours. After this period, roots were beginning to emerge.

Fourteen nylon screens were used, adapted over 14 plastic containers ( $8.3 \mathrm{~L}$ capacity each), containing complete nutrient solutions with $3.875 \mathrm{mg} \mathrm{L}^{-1}$ phosphorus, at $\mathrm{pH} 4.0$ and a temperature of $25 \pm 1^{\circ} \mathrm{C}$. Four populations and both parentals were evaluated on each screen. The evaluated populations are listed in Table 1. About

Table 1 - Number of plants (n), mean, variance, standard error, and coefficient of variation (C.V.) for primary root growth during ten days, in 14 plastic containers containing complete nutrient solution, of populations from crosses involving two wheat genotypes ( $\mathrm{P} 6=\mathrm{BH}-1146$ and $\mathrm{P} 25=$ Kauz"S"/ IAC-24 $\mathrm{M}_{4}$ ) in $\mathrm{F}_{2}, \mathrm{~F}_{3}, \mathrm{~F}_{2} \mathrm{RC}_{1}$, and $\mathrm{F}_{2} \mathrm{RC}_{2}$ generations.

\begin{tabular}{|c|c|c|c|c|c|c|c|}
\hline Container & Population & Cross & $\mathrm{n}$ & Mean & Variance & Standard error & C.V. \\
\hline & & & & $\mathrm{mm}$ & & & $\%$ \\
\hline \multirow[t]{6}{*}{1} & P6 & & 22 & 190.0 & 336.8 & 18.4 & 9.66 \\
\hline & $\mathrm{P} 25$ & & 28 & 114.8 & 141.8 & 11.9 & 10.38 \\
\hline & $\mathrm{F}_{3}$ & $\mathrm{P} 6 / \mathrm{P} 25-1$ & 108 & 166.5 & 671.0 & 25.9 & 15.55 \\
\hline & $\mathrm{F}_{3}$ & P6/P25-2 & 116 & 174.5 & 467.0 & 21.6 & 23.38 \\
\hline & $\mathrm{F}_{3}$ & $\mathrm{P} 6 / \mathrm{P} 25-3$ & 114 & 121.6 & 313.2 & 17.7 & 14.56 \\
\hline & $\mathrm{F}_{3}$ & $\mathrm{P} 6 / \mathrm{P} 25-4$ & 98 & 158.1 & 392.5 & 19.8 & 12.53 \\
\hline \multirow[t]{6}{*}{2} & $\mathrm{P} 6$ & & 22 & 233.2 & 350.0 & 18.7 & 8.02 \\
\hline & $\mathrm{P} 25$ & & 26 & 128.3 & 132.0 & 11.5 & 8.95 \\
\hline & $\mathrm{F}_{3}$ & $\mathrm{P} 6 / \mathrm{P} 25-5$ & 106 & 147.0 & 433.1 & 20.8 & 14.16 \\
\hline & $\mathrm{F}_{3}$ & P6/P25-6 & 111 & 164.7 & 328.4 & 18.1 & 11.00 \\
\hline & $\mathrm{F}_{3}$ & P6/P25-7 & 118 & 132.2 & 426.4 & 20.7 & 15.62 \\
\hline & $\mathrm{F}_{3}$ & $\mathrm{P} 6 / \mathrm{P} 25-8$ & 87 & 179.8 & 397.3 & 19.9 & 11.09 \\
\hline \multirow[t]{6}{*}{3} & P6 & & 22 & 221.3 & 399.4 & 20.0 & 9.03 \\
\hline & $\mathrm{P} 25$ & & 26 & 133.4 & 153.4 & 12.4 & 9.28 \\
\hline & $\mathrm{F}_{3}$ & P6/P25-9 & 111 & 147.1 & 367.3 & 19.2 & 13.03 \\
\hline & $\mathrm{F}_{3}$ & P6/P25-10 & 115 & 163.0 & 438.5 & 20.9 & 12.84 \\
\hline & $\mathrm{F}_{3}$ & P6/P25-11 & 99 & 185.4 & 424.3 & 20.6 & 11.11 \\
\hline & $\mathrm{F}_{3}$ & $\mathrm{P} 6 / \mathrm{P} 25-12$ & 69 & 129.9 & 502.9 & 22.4 & 17.27 \\
\hline \multirow[t]{6}{*}{4} & P6 & & 21 & 219.1 & 346.0 & 18.6 & 8.49 \\
\hline & P25 & & 28 & 126.5 & 133.1 & 11.5 & 9.12 \\
\hline & $\mathrm{F}_{3}$ & $\mathrm{P} 6 / \mathrm{P} 25-13$ & 109 & 150.9 & 443.8 & 21.1 & 13.96 \\
\hline & $\mathrm{F}_{3}$ & P6/P25-14 & 122 & 137.8 & 535.4 & 23.1 & 16.80 \\
\hline & $\mathrm{F}_{3}$ & $\mathrm{P} 6 / \mathrm{P} 25-15$ & 101 & 112.5 & 393.9 & 19.8 & 17.64 \\
\hline & $\mathrm{F}_{3}$ & P25/P6-1 & 80 & 161.2 & 409.4 & 20.2 & 12.55 \\
\hline 5 & P6 & & 22 & 253.2 & 648.3 & 25.5 & 10.06 \\
\hline
\end{tabular}


Table 1 - Continuation.

\begin{tabular}{|c|c|c|c|c|c|c|c|}
\hline & $\mathrm{P} 25$ & & 26 & 159.8 & 282.9 & 16.8 & 10.50 \\
\hline & $\mathrm{F}_{3}$ & $\mathrm{P} 25 / \mathrm{P} 6-2$ & 107 & 188.7 & 370.9 & 19.3 & 10.20 \\
\hline & $\mathrm{F}_{3}$ & P25/P6-3 & 120 & 128.6 & 279.3 & 16.7 & 13.00 \\
\hline & $\mathrm{F}_{3}$ & P25/P6-4 & 115 & 160.2 & 466.2 & 21.6 & 13.48 \\
\hline & $\mathrm{F}_{3}$ & P25/P6-5 & 98 & 158.7 & 896.4 & 29.9 & 18.87 \\
\hline \multirow[t]{6}{*}{6} & P6 & & 26 & 232.4 & 330.7 & 18.2 & 7.83 \\
\hline & $\mathrm{P} 25$ & & 27 & 131.1 & 167.1 & 12.9 & 9.86 \\
\hline & $\mathrm{F}_{3}$ & P25/P6-6 & 115 & 142.2 & 578.0 & 24.1 & 16.94 \\
\hline & $\mathrm{F}_{3}$ & P25/P6-7 & 114 & 169.5 & 461.7 & 21.5 & 12.68 \\
\hline & $\mathrm{F}_{3}$ & $\mathrm{P} 25 / \mathrm{P} 6-8$ & 118 & 148.8 & 306.1 & 17.5 & 11.76 \\
\hline & $\mathrm{F}_{3}$ & $\mathrm{P} 25 / \mathrm{P} 6-9$ & 83 & 175.2 & 346.3 & 18.6 & 10.62 \\
\hline \multirow[t]{6}{*}{7} & P6 & & 24 & 202.0 & 359.9 & 19.0 & 9.39 \\
\hline & P25 & & 26 & 130.3 & 136.4 & 11.7 & 8.96 \\
\hline & $\mathrm{F}_{3}$ & P25/P6-10 & 102 & 139.2 & 450.8 & 21.2 & 15.26 \\
\hline & $\mathrm{F}_{3}$ & P25/P6-11 & 120 & 133.8 & 492.1 & 22.2 & 16.59 \\
\hline & $\mathrm{F}_{3}$ & P25/P6-12 & 110 & 133.2 & 427.0 & 20.7 & 15.52 \\
\hline & $\mathrm{F}_{3}$ & $\mathrm{P} 25 / \mathrm{P} 6-13$ & 83 & 149.9 & 549.8 & 23.4 & 15.64 \\
\hline \multirow[t]{6}{*}{8} & P6 & & 22 & 219.5 & 321.3 & 17.9 & 8.16 \\
\hline & $\mathrm{P} 25$ & & 26 & 118.3 & 192.3 & 13.9 & 11.72 \\
\hline & $\mathrm{F}_{3}$ & P25/P6-14 & 105 & 146.1 & 405.3 & 20.1 & 13.78 \\
\hline & $\mathrm{F}_{3}$ & P25/P6-15 & 118 & 153.4 & 506.1 & 22.5 & 14.66 \\
\hline & $\mathrm{F}_{2}$ & P6/P25-1 & 110 & 163.3 & 517.3 & 22.7 & 13.93 \\
\hline & $\mathrm{F}_{2}$ & P25/P6-1 & 91 & 148.6 & 685.7 & 26.2 & 17.62 \\
\hline \multirow[t]{6}{*}{9} & $\mathrm{P}_{6}$ & & 20 & 180.6 & 135.2 & 11.2 & 6.44 \\
\hline & $\mathrm{P} 25$ & & 25 & 116.6 & 135.2 & 11.6 & 9.97 \\
\hline & $\mathrm{F}_{2}$ & $\mathrm{P} 25 / \mathrm{P} 6-2$ & 109 & 136.3 & 431.0 & 20.8 & 15.23 \\
\hline & $\mathrm{F}_{2}$ & P25/P6-3 & 116 & 141.4 & 477.8 & 21.9 & 15.46 \\
\hline & $\mathrm{F}_{2}$ & $\mathrm{P} 25 / \mathrm{P} 6-4$ & 112 & 128.9 & 494.3 & 22.2 & 17.25 \\
\hline & $\mathrm{F}_{2}$ & $\mathrm{P} 25 / \mathrm{P} 6-5$ & 88 & 146.8 & 359.1 & 19.0 & 12.91 \\
\hline \multirow[t]{6}{*}{10} & P6 & & 23 & 232.0 & 418.0 & 20.4 & 8.81 \\
\hline & P25 & & 25 & 127.0 & 213.7 & 14.6 & 11.51 \\
\hline & $\mathrm{F}_{2}$ & P25/P6-6 & 113 & 161.7 & 643.3 & 25.4 & 15.69 \\
\hline & $\mathrm{F}_{2}$ & P25/P6-7 & 117 & 159.6 & 729.2 & 27.0 & 16.92 \\
\hline & $\mathrm{RC}_{2} \mathrm{~F}_{2}$ & $\mathrm{P} 25 / \mathrm{P} 6 / / \mathrm{P} 25-1$ & 128 & 124.3 & 524.6 & 22.9 & 18.43 \\
\hline & $\mathrm{RC}_{2} \mathrm{~F}_{2}$ & $\mathrm{P} 25 / \mathrm{P} 6 / / \mathrm{P} 25-2$ & 83 & 143.6 & 644.0 & 25.2 & 17.56 \\
\hline \multirow[t]{6}{*}{11} & P6 & & 17 & 232.1 & 433.2 & 20.8 & 8.97 \\
\hline & P25 & & 18 & 143.6 & 168.1 & 13.0 & 9.03 \\
\hline & $\mathrm{RC}_{2} \mathrm{~F}_{2}$ & $\mathrm{P} 25 / \mathrm{P} 6 / / \mathrm{P} 25-3$ & 78 & 146.3 & 950.0 & 30.8 & 21.07 \\
\hline & $\mathrm{RC}_{2} \mathrm{~F}_{2}$ & $\mathrm{P} 25 / \mathrm{P} 6 / / \mathrm{P} 25-4$ & 113 & 161.1 & 603.6 & 24.6 & 15.25 \\
\hline & $\mathrm{RC}_{2} \mathrm{~F}_{2}$ & $\mathrm{P} 25 / \mathrm{P} 6 / / \mathrm{P} 25-5$ & 100 & 151.9 & 484.7 & 21.9 & 14.45 \\
\hline & $\mathrm{RC}_{2} \mathrm{~F}_{2}$ & $\mathrm{P} 25 / \mathrm{P} 6 / / \mathrm{P} 25-6$ & 93 & 167.4 & 501.4 & 22.4 & 13.58 \\
\hline \multirow[t]{6}{*}{12} & P6 & & 20 & 204.7 & 268.8 & 16.4 & 8.01 \\
\hline & P25 & & 26 & 112.1 & 151.4 & 12.3 & 10.98 \\
\hline & $\mathrm{RC}_{2} \mathrm{~F}_{2}$ & $\mathrm{P} 25 / \mathrm{P} 6 / / \mathrm{P} 25-7$ & 102 & 142.9 & 353.6 & 18.8 & 13.16 \\
\hline & $\mathrm{RC}_{1} \mathrm{~F}_{2}$ & P25/P6//P6-1 & 103 & 193.7 & 514.2 & 22.7 & 11.71 \\
\hline & $\mathrm{RC}_{1} \mathrm{~F}_{2}$ & P25/P6//P6-2 & 98 & 169.7 & 361.8 & 19.0 & 11.21 \\
\hline & $\mathrm{RC}_{2} \mathrm{~F}_{2}$ & $\mathrm{P} 6 / \mathrm{P} 25 / / \mathrm{P} 25-1$ & 83 & 156.8 & 731.0 & 27.0 & 17.25 \\
\hline \multirow[t]{6}{*}{13} & P6 & & 22 & 213.6 & 162.3 & 12.7 & 5.96 \\
\hline & P25 & & 25 & 132.4 & 146.8 & 12.1 & 9.15 \\
\hline & $\mathrm{RC}_{2} \mathrm{~F}_{2}$ & $\mathrm{P} 6 / \mathrm{P} 25 / / \mathrm{P} 25-2$ & 107 & 147.0 & 580.0 & 24.1 & 16.37 \\
\hline & $\mathrm{RC}_{2} \mathrm{~F}_{2}$ & $\mathrm{P} 6 / \mathrm{P} 25 / / \mathrm{P} 25-3$ & 114 & 136.9 & 353.0 & 18.8 & 13.72 \\
\hline & $\mathrm{RC}_{2} \mathrm{~F}_{2}$ & $\mathrm{P} 6 / \mathrm{P} 25 / / \mathrm{P} 25-4$ & 108 & 148.7 & 500.5 & 22.4 & 15.05 \\
\hline & $\mathrm{RC}_{1} \mathrm{~F}_{2}$ & P6/P25//P6-1 & 87 & 221.1 & 730.0 & 27.0 & 12.22 \\
\hline \multirow[t]{5}{*}{14} & P6 & & 23 & 229.8 & 270.7 & 14.5 & 7.16 \\
\hline & P25 & & 26 & 127.5 & 190.9 & 13.8 & 10.84 \\
\hline & $\mathrm{RC}_{1} \mathrm{~F}_{2}$ & $\mathrm{P} 6 / \mathrm{P} 25 / / \mathrm{P} 6-2$ & 100 & 164.9 & 731.8 & 27.1 & 16.40 \\
\hline & $\mathrm{RC}_{1} \mathrm{~F}_{2}$ & $\mathrm{P} 6 / \mathrm{P} 25 / / \mathrm{P} 6-3$ & 108 & 174.4 & 804.7 & 28.4 & 16.27 \\
\hline & $\mathrm{RC}_{1} \mathrm{~F}_{2}$ & $\mathrm{P} 6 / \mathrm{P} 25 / / \mathrm{P} 6-4$ & 101 & 175.1 & 583.5 & 24.2 & 17.80 \\
\hline
\end{tabular}


100 seeds from each population and 25 seeds from each parental were selected and placed on each screen with tweezers. Seeds were maintained moist with the emerging roots touching the solutions, therefore obtaining a ready supply of water and nutrients.

The final concentration of the nutrient solution was: $\mathrm{Ca}\left(\mathrm{NO}_{3}\right)_{2} 4 \mathrm{mmol} \mathrm{L}^{-1}, \mathrm{MgSO}_{4} 2 \mathrm{mmol} \mathrm{L}^{-1}, \mathrm{KNO}_{3} 4$ $\mathrm{mmol} \mathrm{L}^{-1},\left(\mathrm{NH}_{4}\right)_{2} \mathrm{SO}_{4} 0.435 \mathrm{mmol} \mathrm{L}^{-1}, \mathrm{KH}_{2} \mathrm{PO}_{4} 0.125$ $\mathrm{mmol} \mathrm{L}^{-1}, \mathrm{MnSO}_{4} 2 \mu \mathrm{mol} \mathrm{L}^{-1}, \mathrm{CuSO}_{4} 0.3 \mu \mathrm{mol} \mathrm{L}^{-1}, \mathrm{ZnSO}_{4}$ $0.8 \mu \mathrm{mol} \mathrm{L}^{-1}, \mathrm{NaCl} 30 \mu \mathrm{mol} \mathrm{L}{ }^{-1}, \mathrm{Fe}-\mathrm{CYDTA} 10 \mu \mathrm{mol} \mathrm{L}^{-1^{4}}$, $\mathrm{Na}_{2} \mathrm{MoO}_{4} 0.10 \mu \mathrm{mol} \mathrm{L}^{-1}$, and $\mathrm{H}_{3} \mathrm{BO}_{3} 10 \mu \mathrm{mol} \mathrm{L}^{-1}$. The 14 solutions were previously adjusted to $\mathrm{pH} 4.0$ with $0.5 \mathrm{~mol}$ $\mathrm{L}^{-1} \mathrm{H}_{2} \mathrm{SO}_{4}$ or $1 \mathrm{~mol} \mathrm{~L}^{-1} \mathrm{NaOH}$. Each solution was continuously aerated and the plastic bowls containing the solutions were placed in a water-bath at a temperature of $25 \pm 1{ }^{\circ} \mathrm{C}$ in the laboratory.

Seedlings were allowed to develop under these conditions for ten days. After this they were removed from each nylon screen for evaluation. The root growth for each plantlet was obtained by measuring central primary root length.

During the entire experiment, the $\mathrm{pH}$ in the nutrient solutions was maintained as near as possible to 4.0 by daily adjustments. Means, variances, standard errors, and coefficients of variation were calculated for all populations.

The degrees of dominance in relation to root growth during ten days in complete nutrient solutions were calculated for each cross in the $\mathrm{F}_{2}$ generation, according to the method proposed by Strickberger (1968). Thus, a degree of dominance equal to +1 would mean the complete dominance of genes that would condition for greater root growth during ten days in complete nutritive solutions, and -1 would mean the complete dominance of genes that would condition for smaller root growth.

Heterosis as well as the percentage of increase of $\mathrm{F}_{2}$ over the parental mean, were calculated by means of the formula described by Matzinger et al. (1962). The superiority of $\mathrm{F}_{2}$ over the parental mean with the highest value for the evaluated character was defined as heterobeltiosis, and was estimated using the formula proposed by Fonseca \& Patterson (1968).

Broad-sense heritability (proportion of genetic variance and phenotypic variance) was calculated following the method cited by Briggs \& Knowles (1977), and narrow-sense heritability (proportion of additive genetic variance and phenotypic variance) by regression of the mean for the $\mathrm{F}_{2}$ 's over the corresponding parental means; the coefficient of determination was calculated by the correlation between the mean for the $\mathrm{F}_{2}$ 's and the corresponding parental means, according to Falconer (1960).

The number of genes $(\mathrm{N})$ contributing to a quantitative character was estimated by the formula proposed by Poehlman \& Sleper (1995):

$$
\mathrm{N}=\left(\bar{x}_{\mathrm{P} 1}{ }_{\mathrm{P} 2}\right)^{2} /\left\{8\left[\left(\sigma_{\mathrm{F} 2}\right)^{2}-\left(\sigma_{\mathrm{F} 1}\right)^{2}\right]\right\}
$$

where: ${ }_{\mathrm{P} 1}$ and ${ }_{\mathrm{P} 2}=\mathrm{P}_{1}$ and $\mathrm{P}_{2}$ parental means; $\sigma_{\mathrm{F} 1}$ and $\sigma_{\mathrm{F} 2}=$ standard errors for the $\mathrm{F}_{1}$ and $\mathrm{F}_{2}$ generations. In this work, the standard error for the $\mathrm{F}_{1}$ generation was replaced by the mean for the parental standard errors.

\section{RESULTS AND DISCUSSION}

The number of plants (n), mean, variance, standard error, and coefficient of variation (C.V.) for the populations in relation to primary root growth during ten days in complete nutrient solution are presented in Table 1.

P6 presented a mean root growth ranging between 180.6 and $253.2 \mathrm{~mm}$, while P25 under the same conditions had a variation between 112.1 and $159.8 \mathrm{~mm}$ (Table 1). Parentals were markedly different in relation to root growth under similar cultivation conditions (nutrient solutions).

Although parentals were self-fertilized for many generations (thus having neared complete homozygosis), differences were observed within each of the parental groups. This variability probably resulted from experimental errors.

Taking into account the distribution frequencies (data not presented), standard errors and coefficients of variation (Table 1), the $\mathrm{F}_{2}$ generation for crosses $\mathrm{P} 6 / \mathrm{P} 25$ or P25/P6 was more variable than the parentals. Despite the fact that the $\mathrm{F}_{2}$ generation is also affected by the environment, the segregation and gene recombination effects were responsible for a large part of the phenotypic variability that existed in this generation.

Individuals from various parts of the distribution curve of an $\mathrm{F}_{2}$ population produced $\mathrm{F}_{3}$ progenies that were markedly different in mean size (varying from 112.5 to $188.7 \mathrm{~mm}$ ). Different $\mathrm{F}_{2}$ individuals produced $\mathrm{F}_{3}$ progenies with different variances (variabilities) (Table 1). Twentynine $\mathrm{F}_{3}$ progenies had smaller variance than the $\mathrm{F}_{2}$ progeny (729.2) which presented the highest value. Only progeny (P25/P6)-5 $\mathrm{F}_{3}$ had a higher observed variance (896.4). This was expected, because an increase in the frequency of homozygous individuals and a consequent reduction in the frequency of heterozygous individuals occur at every self-fertilization generation.

Individuals from various parts of the distribution curve of an $\mathrm{F}_{1}$ population from the $\left(\mathrm{RC}_{1}\right) \mathrm{P} 6 / \mathrm{P} 25 / / \mathrm{P} 6$ or $\mathrm{P} 25 / \mathrm{P} 6 / / \mathrm{P} 6$ backcrosses produced $\mathrm{F}_{2}$ progenies that were markedly different in mean size (varying from 164.9 to $221.1 \mathrm{~mm}$ ) (Table 1). Taking into consideration the individuals from various parts of the distribution curve for an $\mathrm{F}_{1}$ population of the $\left(\mathrm{RC}_{2}\right) \mathrm{P} 6 / \mathrm{P} 25 / / \mathrm{P} 25$ or $\mathrm{P} 25 / \mathrm{P} 6 / / \mathrm{P} 25$ backcrosses, these produced $\mathrm{F}_{2}$ progenies that were markedly different in mean size (varying from 124.3 to 167.4 $\mathrm{mm}$ ) (Table 1). 
Table 2 - Degree of dominance (D.D.), heterosis (h) and heterobeltiosis $\left(h_{b}\right)$, broad-sense heritability estimates $\left(h_{A}{ }^{2}\right)$, and estimates for number of genes involved in primary root growth, during ten days, in plastic container 8, 9, and 10 containing complete nutrient solution, derived from data obtained in parental and $\mathrm{F}_{2}$ generations of crosses involving wheat genotypes (P6=BH-1146 and P25=Kauz"S"/ IAC-24 M $\mathrm{M}_{4}$.

\begin{tabular}{|c|c|c|c|c|c|c|c|}
\hline Container & Generation & Cross & D.D. & $\mathrm{h}$ & $\mathrm{h}_{\mathrm{b}}$ & $\mathrm{h}_{\mathrm{A}}^{2}$ & No. of genes \\
\hline 8 & $\mathrm{~F}_{2}$ & $(\mathrm{P} 6 \times \mathrm{P} 25)-1$ & -0.11 & -3.32 & -25.60 & 50.4 & 5 \\
\hline 8 & $\mathrm{~F}_{2}$ & $(\mathrm{P} 25 \times \mathrm{P} 6)-1$ & -0.40 & -12.02 & -32.30 & 62.5 & 3 \\
\hline 9 & $\mathrm{~F}_{2}$ & $(\mathrm{P} 25 \times \mathrm{P} 6)-2$ & -0.38 & -8.28 & -24.53 & 68.6 & 2 \\
\hline 9 & $\mathrm{~F}_{2}$ & $(\mathrm{P} 25 \times \mathrm{P} 6)-3$ & -0.23 & -4.85 & -21.71 & 71.7 & 2 \\
\hline 9 & $\mathrm{~F}_{2}$ & $(\mathrm{P} 25 \times \mathrm{P} 6)-4$ & -0.62 & -13.26 & -28.63 & 72.6 & 2 \\
\hline 9 & $\mathrm{~F}_{2}$ & $(\mathrm{P} 25 \times \mathrm{P} 6)-5$ & -0.06 & -1.21 & -18.72 & 62.4 & 3 \\
\hline 10 & $\mathrm{~F}_{2}$ & $(\mathrm{P} 25 \times \mathrm{P} 6)-6$ & -0.34 & -9.92 & -30.30 & 50.9 & 5 \\
\hline 10 & $\mathrm{~F}_{2}$ & $(\mathrm{P} 25 \times \mathrm{P} 6)-7$ & -0.38 & -11.09 & -31.21 & 56.7 & 4 \\
\hline
\end{tabular}

The stronger primary root growth trait exhibited by genotype 6 or reduced root growth exhibited by genotype 25 is controlled genetically and is explained by an inheritance of quantitative characters (Allard, 1960). These results indicate that plant selections performed in the early segregating generations for strong or reduced primary root growth would have a great opportunity of being successful.

The degrees of dominance for root growth are presented in Table 2. Genes for stronger root growth found in genotype 6 had a partially recessive behavior in the $\mathrm{F}_{2}$ generation of the cross of this genotype with genotype 25 , with smaller root growth, i.e., the mean for primary root growth in the $\mathrm{F}_{2}$ populations was smaller than the parental mean, but higher than the mean for the parental that had reduced primary root growth (Table 1).

Negative heterosis and heterobeltiosis were observed in the $\mathrm{F}_{2}$ generations, demonstrating that the hybrid means were lower than the mean root growth for the parents herein used, and lower than the mean root growth for the parent that exhibited longer roots, respectively (Table 2). The negative heterosis values of the $\mathrm{F}_{2}$ generation indicated that root growth for this cross was lower than the mean root growth for the parents used, thus confirming the results obtained for degrees of dominance, i.e. partial dominance of the genes that condition for plants with smaller root growth.

The estimated broad-sense heritability for root growth ranged from 50.4 to $72.6 \%$, indicating that a large part of the variation observed in the populations comes from a genetic source (Table 2). The estimated narrowsense heritability for root growth was $75 \%$, showing that a large part of the total genetic variability for this trait is due to a small number of genes, therefore having little environmental influence in its expression. Since a coefficient of determination of 0.73 , significant at $5 \%$ was also obtained for primary root growth, the data suggest that selection for this trait would be effective if made in early segregating generations, thus confirming the results previously discussed.

The number of genes contributing toward the quantitative primary root growth character was estimated by the formula proposed by Poehlman \& Sleper (1995), and varied from 2 to 5 , according to the $\mathrm{F}_{2}$ population under consideration. These results confirmed the data previously discussed, related to the estimates for degrees of dominance and broad- and narrow-sense heritabilities, which suggested that a small number of genes acted on the root growth character. In crosses aimed at breeding, attempts to estimate the number of genes that contribute to a given quantitative character are impracticable (Poehlman \& Sleper, 1995). Frequently, the best a breeder can do is to estimate whether the quantitative character is governed by a relatively large or a relatively small number of genes.

The practical significance of the results is the potential for making successful selections in the initial segregating generations after the cross, for plants that show long primary roots in the early stages of development, for a good establishment of the crop, especially when water deficits occur after the emergence of the seedlings in the field.

\section{CONCLUSIONS}

The primary root growth trait evaluated in nutrient solutions is controlled genetically and is explained by an inheritance of quantitative characters. The genes for stronger root growth found in genotype 6 have a partially recessive behavior when this genotype is crossed with genotype 25 , with smaller root growth. The heterosis and heterobeltiosis values were negative for the primary root growth trait. The observed variation in the populations is, in large part, of additive genetic source and attributed to a small number of genes. Selection for primary root growth can be effectively performed since the initial segregating generations. 


\section{ACKNOWLEDGEMENTS}

To IAEA, Vienna, Austria, for financial support to the project, $\mathrm{CNPq}$ for scholarship, and Maria Catarina Aboin Gomes Camargo for collaboration in obtaining data.

\section{REFERENCES}

ALLARD, R.W. Principles of plant breeding. New York: John Wiley \& Sons, Inc, 1960. 485p.

BAIER, A.C.; SOMERS, D.J.; GUSTAFSON, J.P. Aluminum tolerance in wheat: correlating hydroponic evaluations with field and soil performances. Plant Breeding, v.114, p.291-296, 1995.

BRIGGS, F.N.; KNOWLES, P.F. Introduction to plant breeding. Davis: Reinhold Publishing Corporation, 1977. 426p.

CAMARGO, C.E. de O. A concentração de fósforo na tolerância de cultivares de trigo à toxicidade ao alumínio em soluções nutritivas. Bragantia, v.44, p.49-64, 1985.

CAMARGO, C.E. de O. Trigo. In: FURLANI, A.M.C.; VIEGAS, G.P. (Ed.). O melhoramento de plantas no Instituto Agronômico. Campinas: Instituto Agronômico, 1993. p.433-488.

CAMARGO, C.E. de O.; OLIVEIRA, O.F. Tolerância de cultivares de trigo a diferentes níveis de alumínio em solução nutritiva e no solo. Bragantia, v.40, p.21-31, 1981.

CAMARGO, C.E. de O.; FERREIRA-FILHO, A.W.P. São Paulo State Brazil Wheat Pool. In: BONJEAN, A.P.; ANGUS, W.J. (Ed.) The world wheat book - A history of wheat breeding. Paris: Lavoisier, 2000. chap.21, p.549-577.

CAMARGO, C.E. de O.; FERREIRA-FILHO, A.W.P.; SALOMON, M.V. Temperature and $\mathrm{pH}$ of the nutrient solution on wheat primary root growth. Scientia Agricola, v.61, p.313-318, 2004.

CAMARGO, C.E. de O.; TULMANN-NETO, A.; FERREIRA-FILHO, A.W.P.; FELICIO, J.C. Genetic control of aluminum tolerance in mutant lines of the wheat cultivar Anahuac. Euphythica, v.114, p.47-53, 2000.

CAMARGO, C.E. de O.; OLIVEIRA, O.F.; FERREIRA-FILHO, A.W.P.; CASTRO, J.L. de; RAMOS, V.J. Melhoramento do trigo: VII. Herdabilidade e coeficiente de correlação entre caracteres agronômicos em populações híbridas de trigo, em diferentes solos paulistas. Bragantia, v.43, p.293-312, 1984.
CAMARGO, C.E. de O.; TULMANN NETO, A.; FERREIRA FILHO, A.W.P.; FELICIO, J.C.; CASTRO, J.L. de; PETTINELLI JR., A. Novos genótipos de trigo (Triticum aestivum L.) obtidos por irradiação gama. Scientia Agricola, v.54, p.195-202, 1997.

CAMARGO, C.E. de O.; FERREIRA-FILHO, A.W.P.; RAMOS, L.C. da S.; FELICIO, J.C.; TULMANN-NETO, A. Primary root growth: genetics and differential among wheat mutant lines in nutrient solutions. In: RESEARCH CO-ORDINATION MEETING OF FAO/IAEA COORDINATED RESEARCH PROJECT ON MUTATIONALANALYSIS OF ROOT CHARACTERS IN ANNUAL FOOD PLANTS RELATED TO PLANT PERFORMANCE, 1., Vienna, 2000. Report. Vienna: IAEA, 2002. p.43-46.

CAMPBELL, L.G.; LAFEVER, H.N. Correlation of field and nutrient culture techniques of screening wheat for aluminum tolerance. In: WORKSHOP ON PLANT ADAPTATION TO MINERAL STRESS IN PROBLEM SOILS, Beltsville, 1976. Proceedings. Ithaca: Cornell University, 1976. p.277-286.

FALCONER, D.S. Introduction to quantitative genetics. New York: Ronald Press, 1960. 365p.

FONSECA, S.; PATTERSON, F.L. Yield components, heritabilities and interrelationships in winter wheat (Triticum aestivum L.) Crop Science, v.8, p.614-617, 1968 .

FOY, C.D.; ARMIGER, W.H.; BRIGGLE, L.W.; REID, D.A. Differential aluminum tolerance of wheat and barley varieties in acid soils. Agronomy Journal, v.57, p.413-417, 1965.

MATZINGER, D.F.; MANN, T.J.; COCKERHAM, C.C. Diallel cross in Nicotiana tabacum. Crop Science, v.2, p.383-386, 1962.

POEHLMAN, J.N.; SLEPER, D.A. Breeding field crops. Ames: Iowa State University Press, 1995. 494p.

STRICKBERGER, M.W. Genetics. New York: The Macmillan Company, 1968. 868 p.

$\overline{\text { Received April 22, }} 2004$

Accepted April 26, 2005 